SCIREA Journal of Education

http://www.scirea.org/journal/Education

November 16, 2021

Volume 6, Issue 6, December 2021

\title{
FOREIGN-LANGUAGE COMMUNICATION: INTRODUCTION OF THEOLOGICAL ASPECT AT CONTEMPORARY UNIVERSITY
}

\author{
Natalia V. Gorbunova ${ }^{1}$, Emilia P. Komarova ${ }^{1}$, Svetlana A. Bakleneva ${ }^{2 *}$, Alexandr S. \\ Fetisov $^{3}$, Natalia S. Mahina ${ }^{4}$ \\ ${ }^{1}$ Voronezh State Technical University, Voronezh, Russia 394006 \\ ${ }^{2}$ Military Educational and Scientific Center of the Air Force "N.E. Zhukovsky and Yu.A. \\ Gagarin Air Force Academy"; Voronezh, Russia 394064 \\ ${ }^{3}$ Voronezh State Pedagogical University; Voronezh, Russia 394043 \\ ${ }^{4}$ Voronezh Institute of Economics and Law; Voronezh, Russia 394007 \\ E-mail: maraldo57@mail.ru,vivtkmk@mail.ru,Svetlana bakleneva@mail.ru,asfet- \\ 2011@mail.ru,nnsinn@mail.ru \\ *e-mail: Svetlana baklene@mail.ru, Phone: (+7)915 5817029
}

\begin{abstract}
The relevance of the study is defined by the expansion of the range of socially significant activities of the Russian Orthodox Church in the sphere of peacemaking, missionary work, preservation and development of cultural heritage, which contributes to the intensification of spiritual cooperation between peoples and states, the implementation of which is entrusted to representatives of the Church, including graduates of modern universities. The problem of intercultural communication is of particular relevance to the citizens of the Russian
\end{abstract}


Federation in order to strengthen cooperation and achieve effective interaction between representatives of different cultures and faiths. To this end, the willingness of university students to foreign language communication, which, being a part of spiritual culture, is especially relevant, and is associated not only with the relaying of the system of theological knowledge, including the traditional spiritual values of society and mankind, with theological education and science, religious culture and philosophy, but also with the sphere of interstate confessional and social relations. Participation in international meetings, scientific and practical conferences, symposia, interreligious forums, pilgrimage tours requires a graduate of the university to be able to establish contacts with foreign representatives, readiness and abilities for foreign-language communication in the professional sphere. The purpose of the study is to substantiate the multicultural education by developing foreign-language communication at the university in the context of a theological aspect. Objectives of the research: to clarify the concept of "students' readiness for foreign-language communication" at the university in the context of a theological aspect and distinguish its components, criteria and markers; substantiate the theoretical and methodological basis of students' readiness for foreign-language communication at the university in the context of a theological aspect; identify specific traits of forming readiness for foreign-language communication.

Keywords: foreign-language communication, theological aspect, student, university

\section{Introduction}

In accordance with the concept of modernization of higher education of the Russian Federation (RF) [1], foreign language education is a mandatory component of the student's training, and its practical proficiency is prerequisite for his/her future successful social and professional activity. In accordance with the requirements of the Federal State Educational Standard for Higher Education (FSES HE) [1], it is especially emphasized that professional and academic mobility should be equally developed in both secular and spiritual educational organizations in order to carry out socio-practical, educational, expert advisory, mediation and other activities taking into account the interfaith of the modern world [2].

All the above mentioned allows us to consider the readiness of students for foreign-language communication as the basis of a theological approach in the educational process of the university. 


\section{Literature Review}

A great number of scientific researches were devoted to the problems of theological (the term in FSES HE), spiritual (the term used in scientific and pedagogical literature) education. Studies of philosophers, culturologists, psychologists and teachers Igumn Cyprian (Yashchenko), T.V. Sklyarova, L.V. Troitsky, P.A. Florensky are devoted to various aspects of spiritual education. Contemporary scientific idea is reflected in the theological studies of Archbishop Hilarion (Alfeev), I.A. Ilyin, V.N. Lossky and others. The problem of reform and organization of spiritual education are studied by S.V. Tarasov, S.I. Vorobyov and others. Genesis, the historical roots of spiritual education are examined by V.G. Bezrogov, A.I. Sagarda, A.I. Sidorova and others.

Readiness issues are widely studied in pedagogical and psychological literature. The theoretical basis for the formation of professional readiness in methodology is studied in the researches by of M.I. Dyachenko, N.V. Kuzmina, V.V. Serikov, D.N. Uznadze. Various aspects of the professional readiness of future specialists for certain types of activities are considered in the studies of L.A. Odintsov, V.V. Serikov, Yu.V. Yanotovskaya and others. The formation of the readiness of future specialists for foreign-language communication in professional activities was considered in the works of M.V. Vatutina, S.V. Motorina, J.V. Perepelkina and others.

The problem of intercultural communication is associated with the research on the theory of speech activity (L.S. Vygotsky, A.N. Leontyev, S.L. Rubinstein, etc.); identification of the essence of speech communication in the context of the problem of the relationship between public relations, activity and communication (L.P. Bueva, M.S. Kagan, V.M. Sokovnin); on various aspects of communication and speech culture (G.V. Elizarova, T.A. Ladyzhenskaya, A.A. Potebnya); parameters and functions of foreign language communication were studied by I.L. Bim, L.L. Gurova, R.P. Milrud; psycholinguistic and sociocultural features of foreignlanguage communication were studied by N.D. Arutyunov, P.Ya. Galperin, I.A. Zimnyaya and others; foreign language communication is researched by foreign scientists: D. Crystal, A.S. Kawszynski, G. Weaver, Bachman L. and others.

At the same time, despite the diversity of researches, the problem of the interaction of a foreign language and theology was studied mainly from a religious, historical and cultural position (E.B. Rogachevskaya; N.Y. Ivoilova, N.I. Sazonova and others). However, the 
problem of forming students' readiness for foreign-language communication in the theological aspect has not yet been systematically studied.

The unquestionable importance of the available research, therefore, allows us state that there is insufficient representation of the meaningful characteristics of students' readiness for foreign-language communication in the theological aspect, the consideration of which is necessary to increase the level of readiness for foreign-language communication taking into account the theological aspect, which is important in the modern multi-confessional world.

\section{Methodology}

The methodological basis of the study is:

- systematic approach (A.N. Averyanov, I.V. Blauberg, E.G. Yudin) [3], which allows us to consider the formation of students' readiness for foreign-language communication as a holistic set of components;

- competent approach (A.A. Verbitsky, E.P. Komarova, V.V. A.V. Khutorskaya) [4, 5], focused on creating conditions for the formation of readiness for foreign-language communication taking into account the theological aspect;

- personal-oriented approach (E.V. Bondarevskaya, V.V. Serikov, I.S. Yakimanskaya) [6], which considers the individual characteristics of students in the process of forming their readiness for foreign-language communication, taking into account the theological aspect;

- reflexive approach (M.M. Bakhtin, I.A. Stetsenko, V.I. Slobodchikov) [7], that ensures the development of personal consciousness through assessment of its activity, understanding of its effectiveness, introspection and self-esteem;

- linguacultural approach (V. Gumboldt, A. A. Potebnya, V. A. Maslova) [8], which ensures the development of a valuable attitude towards native and foreign culture among students;

- historical and philosophical approach (E.P. Belozertsev, N. A. Narochnitskaya, A.S. Khomyakov) [8, 9], which implements the historical, social, philosophical, religious and pedagogical aspects of the educational process through the "historical and cultural heritage."

The following principles to the relevant approaches for the formation of students' readiness for foreign language communication from the point of view of the theological aspect at the university were identified: 
- subject-centralism implies the inclusion of the mechanism of subjectivation (I. A. Leskova) [10] and the basic elements of learning - forms, methods, means, technologies - in the structure of foreign-language communication from the point of view of the theological aspect;

- interpersonal interaction of subjects of educational process focuses on dialogization, which acts as an elementary "unit" of the pedagogical process, ensuring the exchange of potential (V.V. Serikov) [6] cultural, knowledgeable, active etc.;

- authenticity ensures the creation of a subject-educational environment of the university, corresponding to the individual, age, gender, cultural, religious characteristics of students;

- dominance of problem situations is manifested in the "infeasibility" (V.V. Serikov) [6] to the system of simple elements, when clearly defined parameters with a set of ready-made easily reproducible solutions are not offered for solving educational and professional problems, which focuses on personal performance and personal responsibility for the result;

- openness of educational information ensures the interaction of the information basis of foreign language communication from the point of view of the theological aspect with the actual knowledge reality and the system of values and meanings of the student.

\section{Materials and Results}

Having studied scientific literature on the problem of students' readiness for foreign language communication in the context of theological aspect, we came to the conclusion that, as an educational institution, modern universities have a number of historical features regarding educational activities carried out in accordance with Federal Educational State Standards for Higher Education.

The purpose of spiritual and moral education, according to V.M. Menshikov, is "spiritual and moral improvement as a norm of the spiritual and moral state of each person, which is physical health for the bodily state of a person" [11, p. 178]. In the process of interaction with the world, the student develops as: 1) a spiritual and moral personality; 2) member of a family; 3) collectivist; 4) the son or daughter of his Fatherland or state; 6) citizen of humanity, [11. p. $181]$.

Learning spirituality means "learning mildness and humility, abstinence and chastity, compassionate love for man, and most of all learning to love God by fulfilling his commandments" [12, p. 45]. "The phenomenon of spirituality, realized as a process of self- 
knowledge, in which the essence of man is deployed, reveals itself to an increasing degree of humanization of a man" [13, p. 117]. At the same time, Yu.N. Kulyutkin emphasizes that "spirituality is an indicator of a person's availability of a value scale of vision of the goals and meanings of human life" [14, p. 80].

On the basis of a retrospective analysis of the organization of the pedagogical process in a modern university, the following peculiarities of the formation of readiness for foreign language communication in the context of theological aspect should be distinguished:

- protection of traditional Russian spiritual and moral values, culture and historical memory, on the basis of which the educational process at the university is built $[15,16]$;

- strategic stability and mutually beneficial international cooperation, which is impossible without the readiness of students to foreign language communication in the context of theological aspect, which allows overcoming barriers in interfaith communication $[15,16]$;

- implementation of the principles of Orthodox pedagogy of Christ-centralism, conciliation and eventuality. Following V.M. Menshikov, Orthodox pedagogy is understood by us as "the process of discovering new knowledge, which is based on the provision of " integrity of faith and knowledge "[11, p. 361];

- integration of foreign language and theological knowledge in the practice of foreign language communication is associated with elements of preaching, fragments of liturgical action, interviews that make it possible to form the readiness of students for foreign language communication: excursions escorted by students who speak foreign language to guest foreigners, participating in pilgrimage tours in holy places, organizing interviews in a foreign language.

Within the framework of these features, guided by the classification of Yu.V. Mitina [17], we identified the English-language lexical base of theological orientation: 1. Words for heavenly powers (the Holy Ghost, angel); words naming apostles, saints (brethren, apostle); 2. Names of ranks of the church hierarchy (bishop, reader, curate, verger). D. Crystal indicates centralization around the lexical dominant "God" [18]; 3. Names of holidays (Easter, Epiphany, Pentecost); prayers and chants (collect, psalm, hymn); service names (Mass, Evensong, Matins); Sacraments (baptism, Eucharist); 4. Concepts of orthodox creed (redemption, resurrection, salvation); words for theological books (the Old Testament, the Bible); 5. Names of architecture (crypt, chapel, nave), church objects (myrrh, pulpit, cassock, 
survice). Traditional religious, theological vocabulary also include the names of adjectives (holy, almighty, heavenly) and verbs (toredeem, tobless, toabsolve).

The main task of pedagogy at the university in the process of forming the readiness of students for foreign-language communication is the development of spiritual and moral identity and ownership, the fate of their people and the Fatherland, based on the formation of such spiritual and moral value as patriotism.

V.M. Menshikov is convinced that the main meaning of all pedagogy from the point of view of the theological aspect is "the desire to connect the "pedagogical case" with the teachings of the Orthodox Church" [11, p. 46-83]. It should be noted that in order to carry out pedagogical activities, the educational process takes into account such disciplines as "Orthodox anthropology," "Psychology," "Orthodox pedagogy."

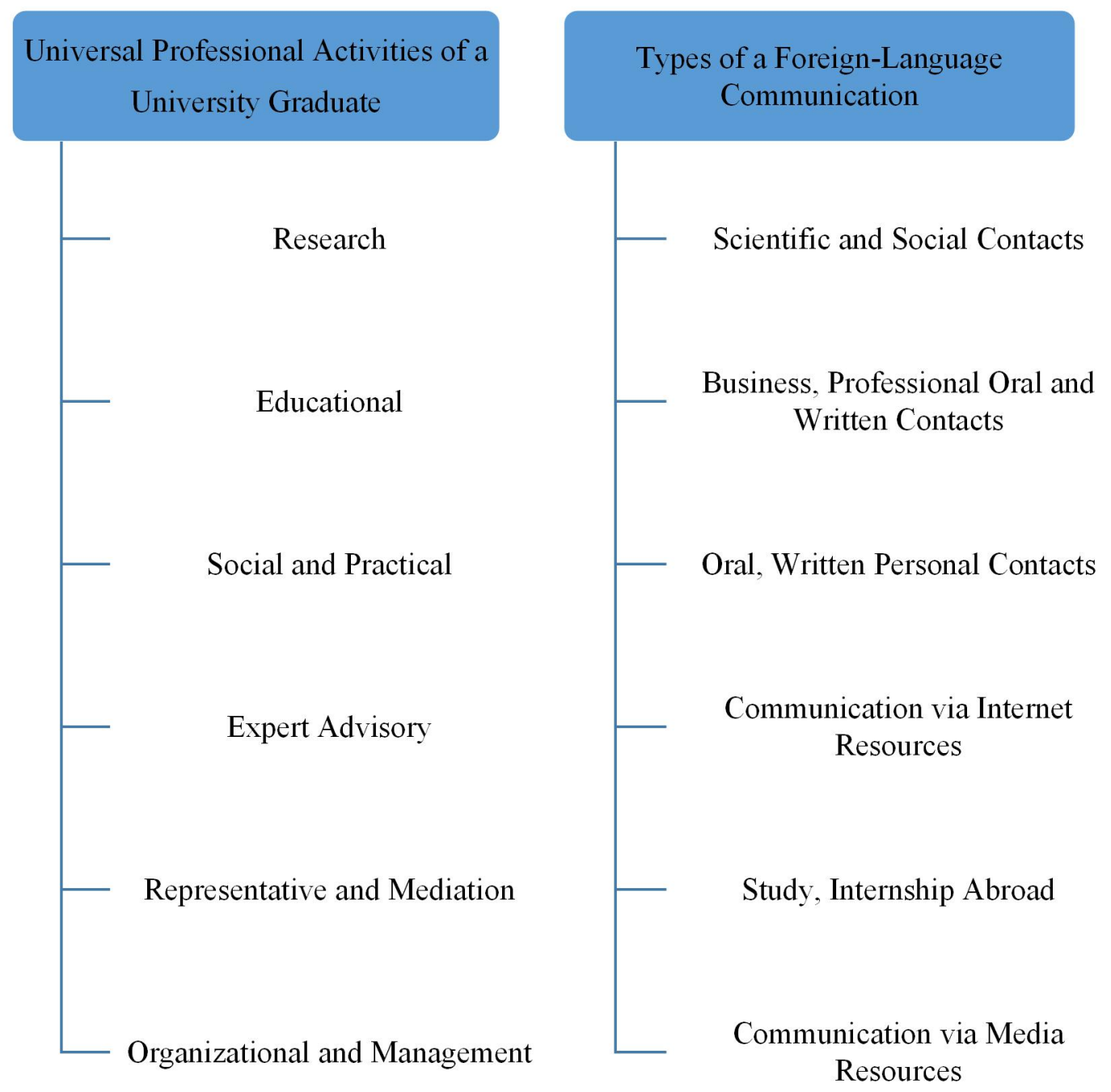

Figure 1. Areas of foreign language application by university students in the context of theological aspect 
Relying on researches by M.V. Vatutina, I.V. Tseneva we consider that readiness is "steady integrative characteristic of the personality, the set of key knowledge, abilities, skills defining suitability to communicative interaction and providing successful performance of professional functions" [19, p. 26].

Summarizing the results of studies on the problem of "readiness" we conclude that this universality acts as an integrative quality of the individual, which is the result of the training process and a systematizing factor in professional activity. In addition, readiness is a complex concept, which includes personal and intellectual readiness, readiness to choose a professional path, awareness of one's own interests, individual psychological characteristics of a personality.

Considering readiness as a complex formation, researchers emphasize the importance of a personal approach to studying the state of readiness and highlight in it the role of cognitive and mental processes that reflect the most important aspects of the activity performed [20, 21, 22]. The role of emotional components, as well as motives of behavior, is emphasized. The readiness of students for professional activity is an indicator of full-fledged educational and industrial training, and its formation is the result of a long learning process [23].

In the process of foreign language training, activities such as speech and communication are priority. Both speech and communication activities are associated with the exchange of information. In particular, speech activities are carried out via language. Communication activities, in addition to language, use other means (for example, non-verbal means of communication).

Thus, readiness for foreign-language communication is considered as an integrative quality of the individual, including the system of value orientations, inclusion in theological knowledge motivated by internal beliefs about the need to strive for self-improvement and self-education taking into account the virtues of the value system, which ensures readiness for successful interaction and cooperation of educational subjects.

Students' readiness for foreign language communication in the theological aspect is ensured by the components described in Table 1 .

Table 1.

\begin{tabular}{|c|c|l|}
\hline Component & Criterion & Indicator \\
\hline Motivational & demand-semantic & $\bullet$ Foreign language information needs; \\
\hline
\end{tabular}




\begin{tabular}{|c|c|c|}
\hline & & - educational and professional motives \\
\hline Cognitive & cognitive-linguistic & $\begin{array}{l}\text { - linguistic abilities; } \\
\text { - extralinguistic and sociocultural knowledge about the } \\
\text { country of the language studied }\end{array}$ \\
\hline Active & $\begin{array}{c}\text { communication and } \\
\text { practical }\end{array}$ & $\begin{array}{l}\text { - the ability to carry out foreign language communication in } \\
\text { compliance with the language and etiquette norms; } \\
\text { - possession of verbal/non-verbal means of communication, } \\
\text { professional proficiency terminology }\end{array}$ \\
\hline Axiological & value-existential & $\begin{array}{l}\text { - leading value dominants of future university graduates; } \\
\text { - focus on value acceptance of foreign language } \\
\text { communication }\end{array}$ \\
\hline Emotional & empathy-behavioural & $\begin{array}{l}\text { - communication self-control; } \\
\text { - ability to overcome the language barrier, } \\
\text { - empathy ability }\end{array}$ \\
\hline
\end{tabular}

\section{Conclusion}

Thus, the indicated methodological basis of the study generates a whole range of progressive pedagogical ideas and achievements, the basis of which was the following methodological approaches: systematic approach, competent approach, personal-oriented approach, reflexive approach, linguacultural approach, historical and philosophical approach and principles: subject-centralism, interpersonal interaction, authenticity, dominance of problem situations, openness of educational information. Developing the readiness of students for foreign language communication in the context of theological aspect presents systemic meaningful characteristics according to the qualification requirements set by FSES HE. This system is based on the following components: motivational, cognitive, active, axiological, emotional, the structural content of which provides the patterns of formation of students' readiness for foreign language communication as a self-organizing systemic complex, due to the internal and external contexts of the interfaith environment of the university.

\section{References}

[1] Federal'niye Gosudarstvenniye Obrazovatel'niye Standarty Visshego Obrazovaniya (Federal State Educational Standards for Higher Education), 2012. http://fgosvo.ru/fgosvo/92/91/4 
[2] Arinin E., Science \& Religion in Russian Post-Soviet Context, in European Journal of Science and Theology, 1, 2005, 51-62

[3] Aver'anova T.A., Razvitie informacionnoj deyatel'nosti studentov (Development of information activities of students), Magnitogorsk, 2006, 180.

[4] Verbickij A.A., O.G. Larionova, Lichnostnyj i Kompetentnostnyj Podhody v Obrazovanii: Problemy Integracii (Personal and Competency Approaches in Education: Integration Challenges), St.-Petersburg, 2017, 336.

[5] Komarova E.P., S.A. Bakleneva, Vektory Razvitiya Professional'nogo Obrazovaniya v Epohu Peremen: Sub'Ektocentrirovannyj Podhod (Vectors of Development of Vocational Education in an Era of Change: a Subject-Centered Approach), Voronezh, 2021, 167.

[6] Serikov V.V., Vektory Razvitiya Kontekstnogo Obrazovaniya: Kollektivnaya Monografiya (Context Education Development Vectors: Collective Monograph), E.P. Komarova (ed.), 2021, 416.

[7] Slobodchikov V.V., Sobytijnaya obrazovatel'naya obshchnost' - istochnik razvitiya i sub"ekt obrazovaniya (Event educational community - the source of development and the subject of education), in Uchenye zapiski Saratovskogo gosudarstvennogo universiteta im N. G. CHernyshevskogo (Scientific Notes of the Saratov State University Named After N. G. Chernyshevsky), 2 (10), 2010, 3-8.

[8] Potebn'a A.A, Slovo I Mif (Word and myth), edn. "Pravda", (1989) 624.

[9] Hom'akov A.S., Sochineniya. V 2 tt. (Writings. In 2 vol.), Moscow, 1994, 589.

[10] Leskova I.A., Sub"ektocentrirovannyj podhod $k$ postroeniyu soderzhaniya vysshego obrazovaniya, Doctoral Thesis, Moscow State University, (2019) 48 c.

[11] Men'shikov V.M., Pravoslavnaya Kul'tura I Razvitie Rossijskogo Vospitaniya I Obrazovaniya (Orthodox Culture and Development of Russian Education), Kursk, (2016) 432.

[12] Kiprian (Kern), archimandrite, Pravoslavnoe pastyrskoe sluzhenie (Orthodox Pastoral Ministry) in Kurs Lekcij Po Pastyrskomu Bogosloviyu (lecture course on Pastoral Theology), St.-Petersburg, (1996) 389.

[13] Nadibaidze O.SH., Rechevaya Kompetenciya Govoryashchego (Speaker's Speech Competence), Moscow, (2009) 189.

[14] Kulyutkin Yu.N., Cennostnye Orientiry i Kognitivnye Struktury v Deyatel'nosti Uchitelya (Values and Cognitive Structures in Teacher Activities), Samara, (2002) 400.

[15] Postanovlenie Pravitel'stva RF ot 20 avgusta 2013 g. № 718 “O federal'noj celevoj programme "Ukreplenie Edinstva Rossijskoj Nacii i Etnokul'turnoe Razvitie Narodov 
Rossii (2014 - $\quad 2020 \quad$ gody)"

(2013).

https://www.garant.ru/products/ipo/prime/doc/70339260/

[16] Ukaz Prezidenta RF' 31.12.2015 N 683 "O Strategii Nacional'noj Bezopasnosti Rossijskoj Federacii", (The Decree of the President of the Russian Federation 31.12.2015 No. 683 "About the Strategy of National Security of the Russian Federation"), (2015) : http://www.consultant.ru/document/cons_doc_LAW_191669/942772dce30cfa36b671bcf $\underline{19 \mathrm{ca} 928 \mathrm{e} 4 \mathrm{~d} 698 \mathrm{a} 928 /}$

[17] Mitina Yu. V., Vocabulary with religious semantics and its stylistic functions in living monuments of the 15th century, PhD Thesis, Moscow State University, (2019) 238.

[18] Crystal D., Investigation English Style, Longman, (1979) 264.

[19] Vatutina M.V., Formirovanie Gotovnosti Budushchih Specialistov Fizkul'turnogo Profilya K Kommunikativnomu Vzaimodejstviyu: Monografiya (Formation of Readiness of Future Specialists of Physical Education Profile for Communicative Interaction: Monograph), Voronezh, (2006) 150.

[20] Gural' S.K., Komarova E.P., Bakleneva S.A., Fetisov A.S., The Theoretical Contex of Integrated Subject and Language Teaching at the University (Theoretical Context of Integrated Subject-Language Training at The University), in Language and Culture, 49 (2020) 138-147.

[21] Komarova E.P., Bakleneva S.A., Lazarev S.V., Fetisov A.S., Subject-Centered Approach to Integrated Language-Professional Training: Backgrounds and Perspectives. 5th International Scientific and Practical Conference 2021 "Modern Science: Problems and Development Prospects (Social and Humanitarian Directions)", Vol.101, (2021) DOI: $10.1051 /$ shsconf/202110103053.

[22] Filippova S., Poarch E., Associative Meaning in Religious Worldview Expression, in European Journal of Science and Theology, 16 (1), (2020) 69-82

[23] Rusu I., Petraru Gh., Influence of Church on Cultural Evolution, in European Journal of Science and Theology, 1 (1), (2005) 3-9. 